諫早湾閉め切りから 20 年，有明海の現状と未来を考える（2）

\title{
Twenty years after the shut-off of Isahaya Bay, the present status and future of Ariake Sea (2)
}

日本ベントス学会自然環境保全委員会

佐藤慎一 ${ }^{1) *}$ ・折田 亮 ${ }^{2)}$ ・ 山川彩子 ${ }^{3)}$ ・ 阿部博和 ${ }^{4)}$ ・松政正俊 ${ }^{4)}$

1) 静岡大学理学部地球科学科。 $\bar{T} 422-8529$ 静岡市駿河区大谷 836

2) 佐賀大学農学部生物資源科学科. $\bar{T} 840-8502$ 佐賀県佐賀市本庄町 1

3) 沖縄国際大学地域環境政策学科。 T901-2701 沖縄県宜野湾市宜野湾 2-6-1

4) 岩手医科大学全学教育推進機構・教養教育センター。 $028-3694$ 岩手県紫波郡矢巾町医大通り 1-1-1

The Nature Conservation Committee, Japanese Association of BenthologyShin' ichi SATO ${ }^{1) *}$, Ryo ORITA ${ }^{2)}$, Ayako YAMAKAWA ${ }^{3)}$, Hirokazu ABE ${ }^{4)}$ and Masatoshi MATSUMASA ${ }^{4}$

1) Institute of Geosciences, Shizuoka University, 836 Oya, Shizuoka 422-8529, Japan

2) Faculty of Agriculture, Saga University, Saga 840-8502, Japan

3) Okinawa International University, 2-6-1 Ginowan, Ginowan City, Okinawa 901-2701, Japan

4) Department of Biology, Center for Liberal Arts \& Sciences, Iwate Medical University, Idaidori 1-1-1, Yahaba-cho, Shiwa-gun, Iwate 028-3694, Japan

日本ベントス学会自然環境保全委員会は, 水域の環境問 題にかかわる科学的な論議と情報を会員ならびに社会に提 供し, 環境保全に関する研究と議論の促進を図るために必 要な事業を行うことを理念として, 1999 年 4 月に発足し た（向井 2000, 逸見 2001). その活動内容は, 学会大会開 催に合わせて環境問題関係の研究集会を開き学会和文誌な どに発表することや, 必要に応じて開発事業の環境影響評 価書に対する意見書や声明の発表を行うことなどである (向井 2000).

本委員会発足のきっかけとなった 1997 年の諌早湾干拓 事業をめぐる問題に関しては, これまでに 6 回の関連シン ポジウムの開催と 4 回の要望書提出が行なわれている（佐 藤 2012a, b, 2013, 2015). 最近では, 2017 年 9 月に滋賀県 立大学で自由集会「渚の自然環境をめぐる諸問題 III 〜自 然環境保全委員会企画自由集会: 諫早湾閉め切りから 20 年, 有明海の現状と未来を考える」を開催し, それらに関 する報告記事と特集を日本ベントス学会誌 73 巻 2 号と 74 巻 1 号にそれぞれ発表した（佐藤ら 2019a, b)

本号（74 巻 2 号）では, 前号に引き続き有明海の現状 報告と今後の対策を検討する特集第 2 弾として, 新たに 3 編の原著論文・総説を掲載する. 首藤らは, 諫早湾潮受け 堤防閉め切り後 5 年間の有明海中央部における底生端脚類 群集の変化について紹介する. 次に, 近藤らが 1998 年か

* Corresponding author sato.shinichi.c@shizuoka.ac.jp
ら 2018 年までに諫早湾干拓調整池から得られたユスリカ 類の群集組成と幼虫密度の経年変化を, 環境要因ならびに 成虫の発生動向とともに解析した成果を報告する。さら に, 佐藤らは諫早湾干拓調整池における水質・底質・大型 底生動物群集の経年変化に関する研究成果を包括的に紹介 することで, 諫早湾の潮止め後に干拓調整池内で何が起 こったのかを考察し, 今後に常時開門した際に生じる現象 を予測する。

これらの特集論文は，今後の要望書提出時などにおい て, 科学的根拠として活用されることが期待できる. 特 に, 2020 年 2 月 21 日から福岡高裁で行われる諫早湾開門 に関する差し戻し審では, 最高裁判所からの補足意見とし て, 2010 年の確定判決後の状況の変化を踏まえて審理す ることが高裁に対して要求されている. 前号と今号に掲載 した特集論文の多くは，2010 年の確定判決以降も有明海 の環境や底生動物群集に改善の兆しは見られず，むしろ深 刻化していることを科学的データとして示しており，それ らに大きな好転が見られたのは堤防閉め切り後 22 年間で 唯一 2002 年（短期開門直後）のみであったことを指摘し ている.これらの科学的事実が福岡高裁での差し戻し審に おいて検討されることが望まれる.

なお，今号の特集論文掲載においても，ベントス学会誌 編集委員会の皆様に多大なご尽力をいただきました。この 場を借りて厚く御礼申し上げます。 


\section{引用文献}

逸見泰久 2001. 特集 1 渚の危機一瀬戸内海 - 九州 - 沖縄の状 況一. 日本ベントス学会誌, 56: 18-20.

向井 宏 2000. 自然環境保全委員会の発足. 日本ベントス学会 誌, 55: 45-46.

佐藤正典 2012a.「有明海の生物多様性保全のための 4 学会合同シ ンポジウム: 有明海の特異な生物相一諌早湾の環境復元の意 義一」の報告. 日本ベントス学会誌, 66: 102-116.

佐藤正典 2012b. 「諫早湾潮受け堤防内に海水を導入する「排水門 開放」の早期実施を求める要望書」の提出. 日本ベントス学会 誌, 67: 33-34.
佐藤正典 2013. 日本ベントス学会公開シンポジウム「有明海・諌 早湾一日本初の大規模な環境復元の意義一」の報告. 日本ベン トス学会誌, 67: 97-100.

佐藤正典 2015. 日本ベントス学会自然環境保全委員会から提出さ れた 3 つの要望書. 日本ベントス学会誌, 70: 21-29.

佐藤慎一・木村妙子・金谷 弦・松政正俊 2019a. 渚の自然環境 をめぐる諸問題 III〜自然環境保全委員会企画自由集会：諫早湾 閉め切りから 20 年, 有明海の現状と未来を考える. 日本ベン トス学会誌, 73: 119-120

佐藤慎一・折田 亮・山川彩子・阿部博和・松政正俊 2019b. 特 集 諫早湾閉め切りから 20 年, 有明海の現状と未来を考える. 日本ベントス学会誌, 74: 41-42. 